\title{
PROFIL PROFESIONALISME GURU MADRASAH IBTIDAIYAH UNGGULAN DI JAKARTA SELATAN
}

\author{
Hasyim Asy'ari \& Asep Ediana Latip \\ UIN Syarif Hidayatullah Jakarta \\ Email : hasyari34@yahoo.co.id; asep_latip@yahoo.com
}

\begin{abstract}
This study aims at formulating a model of the profile of teachers professionalism of excellent Islamic Primary School (IPS). The source of data of this research is obtained from six excelence IPS in South Jakarta that achieve score of accreditation A.This research is a non experimental research that uses survey method. The population of this research is all teachers in 15 Excelence IPS with the sample as much as $40 \%$ of the teachers. as many as 100 teachers. As for the sampling technique used in this research is simple random sampling with descriptive statistics. The result of this research shows that firstly the profile of professionalism of the teachers of excellent IPS in South Jakarta is indicated by adequate teachers competency in personality, pedagogy, professionalism, and social aspect. Secondly, at the dimension of learning community teachers have not fully showed self development as a part of learning community. Thirdly, at the financial dimension it is know that the teachers of especially State Islamic Primary Schools are willing to accept all the policy of reward system set by the goverment and their schools headmasters. Fourtly, the linearity of educational background with the teaching profession. Fifthly, there is no difference in average scores the characteristics of profile of teachers professionalism between Private Islamic Primary Schools and the State ones.
\end{abstract}

Keywords: professionalism, teachers profiles, teacher of excellence islamic primary schools

Abstrak: Penelitian ini bertujuan untuk merumuskan model Profil Profesionalisme Guru MI Unggulan. Sumber data penelitian ini diperoleh dari 6 MI Unggulan di wilayah Jakarta Selatan yang memperoleh akreditasi A. Penelitian ini termasuk jenis penelitian non eksperimental yang menggunakan metode survey. Populasi penelitian ini adalah guru yang mengajar di 15 MI Unggulan dengan sampel $40 \%$ dari guru di MI tersebut, yaitu 100 orang guru. Adapun teknik pengambilan sampelnya simple random sampling. Dalam penelitian ini digunakan teknik analisis data statistik deskriptif. Hasil penelitian menunjukkan pertama, profil profesionalisme guru MI unggulan di Jakarta Selatan ditunjukkan oleh adanya kompetensi guru yang memadai dalam aspek kepribadian, pedagogik, profesionalisme, dan sosial. Kedua, pada dimensi learning community para guru belum sepenuhnya dapat mengembangkan diri sebagai bagian masyarakat pembelajar. Ketiga, pada dimensi finansial dapat diketahui bahwa para guru khususnya MIN bersedia menerima seluruh kebijakan sistem imbalan yang ditetapkan oleh pemerintah dan oleh kepala sekolah mereka. Keempat, linieritas latar belakang pendidikan dengan profesi guru. Kelima, tidak adanya perbedaan dalam nilai rata-rata karakteristik profil profesionalisme guru MIS dan MIN.

Kata Kunci: profesionalisme, profil guru, guru Madrasah Ibtidaiyah unggulan

\section{Pendahuluan}

Pentingnya peran guru profesional, diamanatkan dalam UU No 14 tahun 2005 tentang Guru dan Dosen pasal (1-44) dan Peraturan Pemerintah RI No. 19 tahun 2005 tentang Standar Nasional Pendidikan (Pasal 2844). Esensi kebijakan itu bertujuan meningkatkan kinerja atau pamong penyelenggaraan sistem pendidikan nasional, khususnya jenjang pendidikan dasar dan menengah, yang menyangkut kepentingan sebagian besar hak dan hajat hidup warga masyarakat. Kebijakan itu juga dimaksudkan untuk meletakkan landasan yang kokoh bagi jenjang pendidikan selanjutnya, dengan jalan di satu sisi dimiliki oleh para guru untuk diizinkan menyelenggarakan pelayanan keahlian di 
lapangan, dan di sisi lain menyediakan imbalan yang layak kepada para guru.

Pentingnya peran profesionalitas guru dalam menjalankan tugasnya sebagai pendidik didasarkan pada beberapa alasan berikut: (1) pergeseran paradigma pengelolaan pendidikan dari paradigma pengajaran ke paradigma pembelajaran. Paradigma pengajaran yang lebih menitikberatkan pada peran pendidik dalam mentransformasikan pengetahuan kepada peserta didik bergeser pada paradigma pembelajaran yang memberikan peran lebih besar kepada peserta didik untuk mengembangkan potensi dan kreativitas dirinya dalam rangka membentuk manusia yang memiliki kualitas spiritual keagamaan, berakhlak mulia, berkepribadian, memiliki kecerdasan, memiliki estetika, sehat jasmani dan rohani serta memiliki keterampilan, (2) adanya perubahan pandangan tentang peran manusia dari paradigma manusia sebagai sumber daya pembangunan menjadi paradigma manusia sebagai subjek pembangunan secara utuh, (3) adanya pandangan terhadap peserta didik yang terintegrasi dengan lingkungan sosial-kultural yang pada gilirannya akan menumbuhkan individu sebagai pribadi dan anggota masyarakat yang mandiri dan berbudaya, (4) perlu suatu acuan dasar (brenchmark) oleh setiap penyelenggara dan satuan pendidikan terhadap upaya mewujudkan pendidikan berkualitas dan bermuatan seimbang serta holistik, mendorong kreativitas, bermutu dan terukur, dengan ditandai berkembangnya profesionalisme pendidik atau guru .'

Menurut Mulyasa, salah satu cara upaya revitalisasi pentingnya peran guru dapat dilakukan dengan memotret lembaga pendidikan mitra yang menjadi lapangan praksis dalam pembinaan peserta didik. Lembaga praksis ini adalah lembaga dengan kategori unggulan. Lembaga pendidikan atau sekolah dengan

\footnotetext{
1 Nenden Sri Lengkanawati, Tali Temali Pendidikan dan Pengembangan Profesionalisme Guru, "Pendidikan di Indoneisa: Masalah dan Solusi”, (Jakarta: Kemenko Kesra RI, 2008), h. 36 .
}

kategori unggulan ini memiliki manajemen sekolah/madrasah yang dipastikan banyak perhatian terhadap profesionalitas guru terutama berkenaan dengan pengembangan profesionalismenya. ${ }^{2}$ Menurut Makmun upaya revitalisasi peran guru yang profesional minimal merujuk pada rasionalitas sebagai berikut: (1) karena guru itu menempati posisi dan memegang peranan yang paling strategis dalam sistem pendidikan kapan dan dimana pun. Guru merupakan perwira ujung tombak (front line officer) dalam penyelenggaraan sistem pendidikan, (2) kondisi obyektif profesionalisme guru di negeri ini amat luas variasinya dengan seluk beluk latar belakang historisnya yang cukup unik dan rumit, (3) terbitnya tiga dokumen kebijakan nasional (UUSPN No 20/2000; UUGD No. 14/2005 dan PP No. 19/2005) untuk mengangkat harkat dan martabat profesionalisme guru itu merupakan hal perlu didukung oleh semua pihak yang berkepentingan. $^{3}$

Upaya profesionalisasi secara yuridis formal terus dikembangkan mengingat pentingnya peran guru dalam membantu mencerdaskan bangsa seperti diamanatkan UU Sisdiknas tahun 2003. Profesionalisasi guru berdasarkan Sisdiknas tahun 2003 yang ditetapkan oleh Badan Standar Nasional harus memiliki kompetensi yang berkualitas yang terdiri dari kompetensi pedagodik, kepribadian, sosial, dan profesional. Pada komponen profesional guru, dalam standar Nasional Pendidikan, penjelasan 28 ayat 3 butir c. dikemukakan bahwa yang dimaksud dengan kompetensi profesional adalah kemampuan penguasaan materi pembelajaran secara luas dan mendalam yang memungkinkan membimbing peserta didik memenuhi standar kompetensi yang ditetapkan dalam standar nasional pendidikan.

\footnotetext{
2 E. Mulyasa, Standar Kompetensi dan Sertifikasi Guru, (Bandung: PT. Remaja Rosdakarya,2009), h. 70.

3 Abin Syamsudin Makmun, Sistem Pendidikan dan Pengembangan Nasional, (Jakarta : Rineka Cipta, 2008), h. 190.
} 
Secara eksplisit juga dalam UU Sisdiknas No. 20 disebutkan bahwa guru yang profesional harus memenuhi syarat sebagai berikut : (1) memiliki latar belakang pendidikan dan pelatihan sesuai dengan bidang profesinya, (2) memperoleh kehormatan dan penghargaan dari masyarakat atas jasa pengabdian pada bidang profesinya, (3) menjadi anggota organisasi profesi yang memperoleh pengakuan secara nasional maupun internasional, (4) melaksanakan tugas berdasarkan kode etik profesi guru dan (5) memperoleh penghasilan layak yang ditetapkan berdasarkan atas prestasi dan mencerminkan martabat guru yang profesional, termasuk kesejahteraan, jaminan sosial, dan perlindungan hukum dalam menjalankan profesinya.

Di samping itu, dalam rumusan National Board for Professional Teaching Standars, Lengkanawati menjelaskan prestasi mencerminkan martabat guru yang profesional, termasuk kesejahteraan, jaminan sosial, dan perlindungan hukum dalam menjalankan profesinya. ${ }^{4}$

Di samping itu, dalam rumusan National Board for Profesional Teaching Standars, Lengkanawati menjelaskan lima ciri mendasar guru yang profesional yaitu: (1) teachers are coommited to students and their learning, (2) teachers know the subjects they teach and how to teach those subjects to students, (3) teachers are responsible for managing and monitoring student learning, (4) teachers are try enhance result study of their students..

Berdasarkan latar belakang masalah di atas, dapat dirumuskan bahwa penelitian ini akan mengkaji tentang bagaimanakah Profil Profesionalisme Guru MI Unggulan di Jakarta Selatan? Oleh karena itu penelitian ini bertujuan untuk mendapatkan informasi dan merumuskan model Profil Profesionalisme Guru MI Unggulan di Jakarta Selatan. Hasil penelitian ini

\footnotetext{
${ }^{4}$ Nenden Sri Lengkanawati, Tali Temali Pendidikan dan Pengembangan Profesionalisme Guru, h. 59.
}

diharapkan dapat digunakan sebagai data dan informasi konstruktif untuk: (1) merumuskan kriteria profil guru MI Unggulan, (2) mereview hasil penelitian tersebut.

Namun demikian dari sejumlah harapan tentang pengembangan profesionalisme guru di atas dengan sejumlah kriteria profesionalnya, ada informasi berkenaan dengan rendahnya profesionalitas guru di Indonesia yang ditelisik oleh Makmun bahwa dari total guru yang menjadi peserta pengisian portofolio sertifikasi guru sebagai salah satu instrumen profesionalisasi guru di sekolah ternyata hanya sekitar 20-30\% saja yang dapat dinyatakan lolos uji sertifikasi itu. Hal ini berarti sekitar $70-80 \%$ dari total populasi guru itu masih belum memenuhi syarat profesinolasime guru. Implikasinya, jika total perkiraan kasar terdapat dua orang guru yang perlu diikutkan dalam sertifikasi maka akan terdapat 1.400.000-1.600.000 lagi yang perlu dipersiapkan terlebih dahulu, dengan memperhatikan latar belakangnya yang amat beragam sebagaimana disebut terdahulu. Seperti juga dijelaskan oleh Zuchdi bahwa kenyataan guru di Indonesia, secara yuridis formal diakui bahwa guru itu sebagai pendidik profesional. Akan tetapi, realitasnya sebagian besarnya guru masih dalam proses sertifikasi dan bahkan sebagian besar tidak lulus sertifikasi sebagai salah satu bentuk alat pengembangan profesi guru. ${ }^{5}$

Berdasarkan latar belakang masalah di atas, dapat dirumuskan bahwa penelitian ini akan mengkaji tentang bagaimanakah Profil Profesionalisme Guru MI Unggulan di Jakarta Selatan? Oleh karena itu penelitian ini bertujuan untuk mendapatkan informasi dan merumuskan model Profil Profesionalisme Guru MI Unggulan di Jakarta Selatan. Hasil penelitian ini diharapkan dapat digunakan sebagai data dan informasi konstruktif untuk: (1) merumuskan

5 Darmiyati Zuchdi, Humanisasi Pendidikan: Menemukan Kembali Pendidikan yang Manusiawi, (Jakarta: Bumi Aksara, 2009), h. 124. 
kriteria profil guru MI Unggulan, (2) mereview hasil penelitian tersebut.

Sumber data penelitian ini diperoleh dari 6 MI Unggulan di wilayah Jakarta Selatan yang memperoleh akreditasi A. Enam MI tersebut terbagi atas 2 kelompok yaitu 3 MIN (MIN Bintaro, MIN Petukangan, MIN Pondok Pinang) dan 3 MIS (MI Madrasah Pembangunan, MI Fatahilah, MI Manarul Cilandak). Populasi penelitian ini adalah guru yang mengajar di 15 MI Unggulan. Adapun sampel yang dipilih adalah sekitar $40 \%$ dari para guru yang mengajar di $6 \mathrm{MI}$ unggulan tersebut. Alasan pemilihan lokasi sampel penelitian ini adalah karena banyak madrasah dan sekolah dengan kriteria unggulan sehingga diasumsikan mereka memiliki kualifikasi guru unggulan sehingga dapat dirumuskan tentang profil profesionalisme guru MI unggulan yang dapat dijadikan model bagi madrasah yang lain. Adapun teknik pengambilan sampel yang digunakan dalam penelitian ini yakni simple random sampling.

Metode penelitian yang digunakan adalah survei yakni dengan cara memberikan kuesioner kepada responden dengan cara mengisi angket yang sudah disiapkan. Penentuan metode ini didasarkan pada tujuan penelitian ini yaitu untuk menelusuri dan merumuskan kriteria profil profesionalisme guru di MI unggulan. Penelitian ini termasuk jenis penelitian non eksperimental. oleh karena itu, tidak dilakukan manipulasi pada variabel penelitian. Variabel penelitian ini tidak dapat dikontrol secara langsung karena merupakan variabel yang sudah ada sebelum penelitian dilakukan. Dalam hal ini, variabel penelitian yang dimaksud adalah profesionalisme guru MI unggulan. Adapun teknik pengumpulan data penelitian ini adalah teknik kuesioner dan wawancara.

Analisis data penelitian ini dilakukan terhadap data berdasarkan variabel penelitian ini yaitu dengan cara mentabulasi data, menyajikan data, dan melakukan perhitungan dengan teknik statistik. Dari beberapa teknik statistik dalam penelitian kuantitatif, dalam penelitian ini digunakan teknik analisis data statistik deskriptif. Teknik ini digunakan karena penelitian ini diorientasikan untuk mendeskripsikan data sampel, dan tidak diorientasikan untuk membuat kesimpulan yang berlaku untuk populasi yaitu untuk mendapatkan gambaran distribusi subjek penelitian berdasarkan wilayah, jumlah subjek yang memiliki kriteria profesionalisme guru MI unggulan.

\section{Pembahasan \\ Deskripsi Data Penelitian}

Deskripsi data penelitian dikelompokkan berdasarkan pada data yang menjadi core dalam penelitian yaitu:

(1) Dimensi kompetensi kepribadian

Kecenderungan penyebaran data pada aspek ini menunjukkan angka variatif sebagaimana tabel berikut:

Tabel 1. Nilai Rata-rata Kompetensi Kepribadian

\begin{tabular}{llllllll}
\hline \begin{tabular}{l} 
Pernyataan \\
\multicolumn{1}{r}{$\mathbf{N}$}
\end{tabular} & & $\mathbf{0 1}$ & $\mathbf{0 2}$ & $\mathbf{0 3}$ & $\mathbf{0 4}$ & $\mathbf{0 5}$ & $\mathbf{0 6}$ \\
& $\begin{array}{r}\text { Valid } \\
\text { Missin }\end{array}$ & 84 & 84 & 84 & 84 & 84 & 84 \\
& $\mathbf{g}$ & & 0 & 0 & 0 & 0 & 0 \\
& & & & & & & \\
Mean & 3.45 & 3.59 & 2.97 & 3.25 & 3.55 & 2.94 \\
Std. Error of Mean & .06 & .06 & .09 & .08 & .06 & .09 \\
Median & 4.00 & 4.00 & 3.00 & 3.00 & 4.00 & 3.00 \\
Mode & 4.00 & 4.00 & 3.00 & 4.00 & 4.00 & 3.00 \\
Std. Deviation & .62 & .56 & .83 & .80 & .62 & .86 \\
Variance & .395 & .316 & .698 & .648 & .394 & .755 \\
Minimum & 2.00 & 2.00 & 1.00 & .00 & 2.00 & .00 \\
Maximum & 4.00 & 4.00 & 4.00 & 4.00 & 4.00 & 4.00 \\
Sum & 290 & 302 & 250 & 273 & 299 & 247 \\
\hline
\end{tabular}

Tabel di atas menggambarkan bahwa responden secara umum menyatakan mereka memiliki kompetensi kepribadian yang baik. Angka rata-rata butir pernyataan nomor 1, 2, 4 dan 5 di atas 3,46. Pada butir pernyataan no 3 dan 6 masih tergolong cukup baik yakni 2,9, meskipun untuk nilai rata-rata butir 1-6 masih tinggi yakni 3,29. Hal ini berarti para guru Madarasah Ibtidaiyah unggulan di wilayah Jakarta Selatan memiliki kompetensi kepribadian yang tinggi karena nilai 3,29 masuk kategori baik 
dalam skala 2-4. Jadi berdasarkan penjelasan di atas, bahwa profil guru MI unggulan harus memiliki kompetensi kepribadian yang tinggi dengan kriteria sebagai beriktu: (1) konsistensi dalam perkataan dan perbuatan, (2) memiliki etos kerja, (3) menjadi teladan bagi siswa dan guru yang lain, (4) keterbukaan dalam berpikir, (5) tegas terhadap siswa yang melanggar aturan sekolah, (6) dihormati oleh siswa dan guru lain.

Berdasarkan deskripsi data di atas diperoleh kesimpulan bahwa profil kepribadian seorang guru pada Madrasah Ibtidaiyah dengan kategori unggulan memiliki tingkat kompetensi kepribadian yang tinggi yaitu berkisar pada skor 3.29 untuk skala 1-4. Kompetensi kepribadian yang diharapkan dimiliki oleh seorang guru MI unggulan di wilayah Jakarta Selatan yaitu memiliki karakteristik konsisten dalam perkataan dan perbuatan, etos kerja, menjadi teladan bagi siswa dan guru yang lain, keterbukaan dalam berpikir, tegas terhadap siswa yang melanggar aturan sekolah, dihormati oleh siswa dan guru lain. Hal ini sesuai dengan yang dijelaskan dalam Standar Nasional Pendidikan bahwa kompetensi kepribadian menjadi profil utama bagi seorang guru dalam menjalankan tugas pendidikannya.

(2) Dimensi Kompetensi Pedagogik

Dalam Tabel berikut terdapat gambaran bahwa nilai rata-rata data kompetensi pedagogik termasuk dalam kategori tinggi yakni 3,31. (Angka ini diperoleh dari mean pernyataan nomor 07-13). Hal ini berarti guru secara umum memiliki kompetensi pedagogik yang memadai dalam mengajar.

Tabel 2. Kompetensi Pedagogik

\begin{tabular}{|c|c|c|c|c|c|c|c|c|}
\hline Pernyataan & & 07 & 08 & 09 & 10 & 11 & 12 & 13 \\
\hline $\mathrm{N}$ & Valid & 84 & 84 & 84 & 84 & 84 & 84 & 84 \\
\hline & Missing & 0 & 0 & 0 & 0 & 0 & 0 & 0 \\
\hline Mean & & 3.27 & 3.19 & 3.16 & 3.41 & 3.73 & 3.38 & 3.03 \\
\hline Std. Error of Mean & & .080 & .083 & .082 & .085 & .053 & .079 & .093 \\
\hline Median & & 3.00 & 3.00 & 3.00 & 4.00 & 4.00 & 4.00 & 3.00 \\
\hline Mode & & $3.00 \mathrm{a}$ & 3.00 & 3.00 & 4.00 & 4.00 & 4.00 & 3.00 \\
\hline Std. Deviation & & .733 & .767 & .757 & .779 & .493 & .726 & .856 \\
\hline Variance & & .539 & .590 & .574 & .607 & .244 & .528 & .734 \\
\hline Range & & 3.00 & 4.00 & 4.00 & 4.00 & 2.00 & 3.00 & 3.00 \\
\hline Minimum & & 1.00 & .00 & .00 & .00 & 2.00 & 1.00 & 1.00 \\
\hline Maximum & & 4.00 & 4.00 & 4.00 & 4.00 & 4.00 & 4.00 & 4.00 \\
\hline Sum & & 275 & 268 & 266 & 287 & 314 & 284 & 255 \\
\hline
\end{tabular}

Hal yang menarik pada kompetensi pedagogik guru Madrasah Ibtidaiyah unggulan adalah adanya temuan data yang sangat tinggi yakni pada butir instrumen nomor 11 dengan nilai rata-rata 3,73 dan nilai rata-rata terendah pada butir pernyataan nomor 13 yakni 3,03. Dua temuan data frekuensi kompetensi pedagogik di atas yaitu: (1) memberikan penilaian proses dan hasil belajar secara objektif, (2) memfasilitasi siswa untuk bimbingan belajar.

Berdasarkan deskripsi data di atas diperoleh kesimpulan bahwa profil pedagogik seorang guru pada Madrasah Ibtidaiyah dengan kategori unggulan memiliki tingkat kompetensi pedagogik yang tinggi yaitu berkisar pada skor 3.31 untuk skala $1-4$. Kompetensi pedagogik yang diharapkan dimiliki oleh seorang guru MI unggulan diwilayah Jakarta Selatan yaitu memiliki karakteristik kemampuan yang memadai dalam hal mengenal karakteristik pribadi siswa, menyusun perencanaan pembelajaran dengan baik sesuai kurikulum, menerapkan metode pembelajaran variatif, menciptakan iklim kelas yang nyaman, memberikan penilaian proses dan hasil belajar secara objektif, membimbing siswa yang mengalami kesulitan belajar, dan memfasilitasi siswa untuk bimbingan belajar. Hal ini sesuai dengan yang dijelaskan dalam Standar Nasional Pendidikan bahwa kompetensi pedagogik menjadi profil utama bagi seorang guru dalam menjalankan tugas pendidikannya. 
(3) Dimensi Kompetensi Profesional

Tabel berikut terdapat gambaran bahwa nilai rata-rata data kompetensi profesional termasuk dalam kategori tinggi yakni 3,34. Hal ini berarti guru secara umum memiliki kompetensi profesional yang memadai dalam mengajar.

Tabel 3. Kompetensi Profesional

\begin{tabular}{|c|c|c|c|c|c|}
\hline Pernyataan & 14 & 15 & 16 & 17 & 18 \\
\hline \multirow[t]{2}{*}{$\mathrm{N}$} & 84 & 84 & 84 & 84 & 84 \\
\hline & 0 & 0 & 0 & 0 & 0 \\
\hline Mean & 3.63 & 3.28 & 3.29 & 3.28 & 3.22 \\
\hline Std. Error of Mean & .062 & .060 & .07533 & .07 & .08 \\
\hline Std. Deviation & .57 & .55 & .69 & .66 & .75 \\
\hline Variance & .332 & .303 & .477 & .448 & .563 \\
\hline Minimum & 2.00 & 2.00 & 2.00 & 2.00 & 1.00 \\
\hline Maximum & 4.00 & 4.00 & 4.00 & 4.00 & 4.00 \\
\hline Sum & 305 & 276 & 277 & 276 & 271 \\
\hline
\end{tabular}

Pada tabel di atas pernyataan yang mendapat nilai rata-rata tertinggi adalah butir nomor 14 tentang penguasaan materi yang diajarkan dengan skor 3,63. Artinya dalam hal ini guru sangat menguasai materi. Berdasarkan deskripsi data di atas diperoleh kesimpulan bahwa profil profesionalisme seorang guru pada Madrasah ibtidaiyah dengan kategori unggulan memiliki tingkat kompetensi profesional yang tinggi yaitu berkisar pada skor 3.34 untuk skala 1-4. Kompetensi profesional yang diharapkan dimiliki oleh seorang guru MI unggulan diwilayah Jakarta Selatan yaitu memiliki karakteristik menguasai materi, memiliki wawasan yang luas, dapat memberikan contoh nyata sesuai materi ajar, memperluas wawasan, dan memperdalam pengetahuan sesuai bidang tugasnya. Hal ini sesuai dengan Standar Nasional Pendidikan bahwa kompetensi profesional menjadi profil utama bagi seorang guru dalam menjalankan tugas pendidikannya.

(4) Dimensi Sosial

Dalam Tabel berikut terdapat gambaran bahwa nilai rata-rata data kompetensi sosial termasuk dalam kategori tinggi yakni 2,86. Angka tersebut diperoleh dari mean nomor pernyataan 19-23. Hal ini berarti guru secara umum memiliki kompetensi sosial masuk dalan kategori cukup baik.

Tabel 4. Kompetensi Sosial

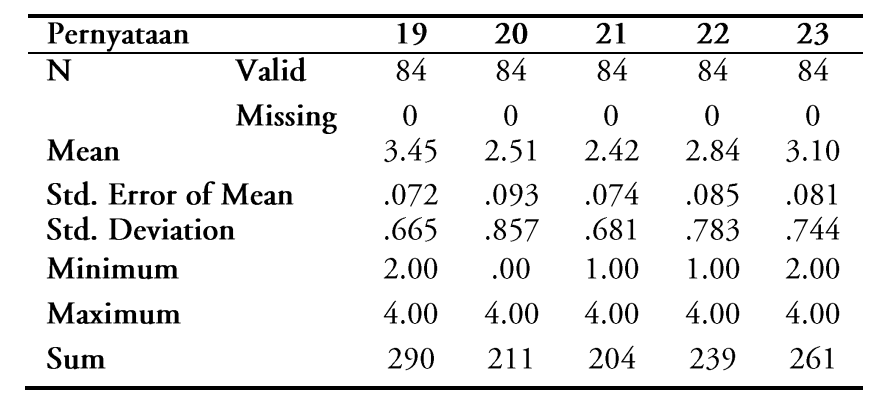

Tabel di atas menggambarkan bahwa responden secara umum menyatakan mereka memiliki kompetensi sosial cukup baik. Angka rata-rata butir pernyataan nomor 19 dan 23 termasuk dalam kategori baik yakni rata-rata 3,27. Sedangkan butir pernyataan nomor 20-22 masuk dalam kategori cukup yakni rata-rata 2,59. Pada butir pernyataan no 3 dan 6 masih tergolong cukup baik yakni 2,9. Fakta ini menunjukkan kecenderungan para guru memiliki kompetensi sosial cukup baik karena nilai 2,26 masuk kategori cukup dalam skala empirik 2-4. Hal ini berarti bahwa fakta empirik tersebut memberikan gambaran adanya kesenjangan terkait profil kompetensi sosial guru sebagaimana harapan pemenuhan standar kompetensi sosial yang ideal. Distribusi frekuensi pilihan responden dapat dilihat dari tabel berikut: (1) suka menanyakan keadaan siswa, (2) suka menyampaikan saran kepada kepala sekolah, (3) suka bersilaturahim kepada orang tua siswa, (4) suka diskusi dengan guru lain. Berdasarkan deskripsi data di atas diperoleh kesimpulan bahwa profil seorang guru pada Madrasah Ibtidaiyah dengan kategori unggulan memiliki tingkat kompetensi sosial yang cukup tinggi yaitu berkisar pada skor 2,86 untuk skala 2-4. Kompetensi sosial yang diharapkan dimiliki oleh seorang guru MI unggulan diwilayah Jakarta Selatan yaitu memiliki karakteristik suka menanyakan keadaan siswa, suka menyampaikan saran kepada kepala sekolah, suka bersilaturahim kepada orang tua siswa, suka sharing ide dengan 
para staf sekolah untuk kemajuan layanan sekolah, dan suka diskusi dengan guru lain untuk peningkatan kualitas belajar siswa. Kriteria tersebut sangat penting meskipun fakta empirik menunjukkan guru MI unggulan di wilayah Jakarta Selatan masih perlu untuk meningkatkan kompetensi sosial untuk memenuhi standar kompetensi ideal yang dibutuhkan.

\section{(5) Dimensi Learning Comunity}

Tabel berikut menjelaskan tingkat komitmen guru sebagai bagian dari masyarakat sekolah untuk mengembangkan diri dengan cara belajar mandiri dan terlibat aktif dalam organisasi profesi.

Tabel 5. Learning community

\begin{tabular}{lccc}
\hline Pernyataan & & 24 & 25 \\
\hline $\mathrm{N}$ & Valid & 84 & 84 \\
& Missing & 0 & 0 \\
Mean & & 3.32 & 2.53 \\
Std. Error of Mean & .08988 & .08544 \\
Std. Deviation & .82375 & .78305 \\
Minimum & .00 & 1.00 \\
Maximum & 4.00 & 4.00 \\
\hline
\end{tabular}

Tabel di atas menunjukkan nilai rata-rata Learning Comunity guru adalah 2,92. Hal ini berarti guru masih perlu berusaha maksimal untuk menjadi bagian masyarakat pembelajar. Tabel frekuensi yang akan ditampilkan adalah pernyataan nomor 25 di mana sebagian guru masih belum terlibat aktif dalam organisasi profesi, di antara kriterianya adalah (1) memiliki komitmen belajar sesuai penugasan, (2) mengikuti organisasi profesi. Berdasar pada deskripsi data ini dapat diambil kesimpulan bahwa guru MI di Jakarta Selatan memiliki kemauan sebagai masyarakat pembelajar yang cukup baik yakni dengan angka rata-rata 2,92. Angka ini sebenarnya belum maksimal dan seharusnya bisa ditingkatkan lebih baik lagi untuk menjadi barometer bagi institusi pendidikan lain. Dimensi ini sangat penting bagi MI untuk bisa memiliki daya saing tinggi dibanding sekolah lain. Guru dan warga sekolah harus mampu mengembangkan dimensi tersebut secara baik.
Upaya-upaya yang dilakukan oleh kepala sekolah untuk pengembangan kompetensi antara lain dalam bentuk pelatihan, seminar, dan workshop. Hal ini sebagaimana dinyatakan oleh kepala MIN Bintaro dan Petukangan bahwa setiap 3 bulan kepala sekolah menyelenggarakan pelatihan-pelatihan. ${ }^{6}$

(6) Dimensi Disiplin Ilmu

Tabel berikut menunjukkan profesi guru para guru sudah sesuai dengan latar belakang pendidikan. Nilai-nilai rata-rata yang dicapai adalah 3,30 artinya sebagian besar responden menyatakan hal yang sama yakni ada kesesuaian antara latar belakang pendidikan dengan profesi guru yang mereka tekuni selama ini.

Tabel 6. Latar Belakang Pendidikan

\begin{tabular}{lll}
\hline Pernyataan & & 28 \\
\hline $\mathrm{N}$ & Valid & 84 \\
& Missing & 0 \\
Mean & & 3.30 \\
Std. Error of Mean & .107 \\
Minimum & .00 \\
Maximum & 4.00 \\
Sum & & 278.00 \\
\hline
\end{tabular}

Deskripsi data di atas memberikan gambaran bahwa dimensi profesi para guru MI di Jakarta selatan sudah seusai dengan disiplin ilmu yang mereka miliki. Linearitas tersebut menjadi sangat penting dalam kerangka untuk menjamin mutu pendidikan di MI. Kepala sekolah dalam hal ini perlu terus berusaha secara maksimal untuk mengembangkan potensi para guru. Pemanfaatan disiplin ilmu yang maksimal menjadi kunci keberhasilan MI dalam mencapai keunggulan yang mereka harapkan.

(7) Dimensi Finansial

Tabel berikut menunjukkan penyebaran data terkait Dimensi Finansial. Nilai rata-rata yang dicapai adalah 3,30 artinya sebagian besar responden mengakui bahwa sistem imbalan yang diterapkan bagi para guru sudah dianggap cukup baik meskipun dari sisi jumlah penghasilan masih relatif. Nilai tertinggi adalah pada butir

\footnotetext{
${ }^{6}$ Wawancara Pribadi, dengan Kepala Sekolah MIN Bintaro dan MIN Petukangan Jakarta Selatan.
} 
pernyataan nomor 27 yakni tentang semangat mengajar guru tidak tergantung gaji, dan nilai rata-rata terendah adalah pada butir pernyataan 29 yakni tentang insentif dari sekolah.

Tabel 7. Dimensi Finansial

\begin{tabular}{|c|c|c|c|c|c|c|}
\hline Pernyataan & & 26 & 27 & 29 & 30 & $\begin{array}{c}\text { Jumlah } \\
\text { Total }\end{array}$ \\
\hline \multirow[t]{2}{*}{$\mathbf{N}$} & Valid & 84 & 84 & 84 & 84 & 84 \\
\hline & Missing & 0 & 0 & 0 & 0 & 0 \\
\hline & & 2.72 & 3.53 & 2.42 & 3.13 & 95.03 \\
\hline \multicolumn{2}{|c|}{ Std. Error of Mean } & .136 & .076 & .132 & .095 & 1.377 \\
\hline \multicolumn{2}{|c|}{ Minimum } & .00 & 1.00 & .00 & 1.00 & 64.00 \\
\hline \multicolumn{2}{|l|}{ Maximum } & 4.00 & 4.00 & 4.00 & 4.00 & 116.00 \\
\hline \multicolumn{2}{|l|}{ Sum } & 229 & 297 & 204 & 263 & 7983 \\
\hline
\end{tabular}

Jika data di atas dilihat dari distribusi frekuensi maka akan diketahui tingkat penyebaran responden dalam memberikan pilihan jawaban pada nomor pernyataan tersebut. Sebagai contoh pada pernyataan nomor 27 bahwa 54 responden (64,3\%) menyatakan semangat mengajar mereka tidak tergantung gaji dan hanya 1 responden yang menyatakan semangat mengajar tergantung pada gaji yang diterima. Data di atas menunjukkan 24 responden $(28,6 \%)$ guru selalu menerima insentif dari sekolah di luar gaji pokok dan tunjangan sertifikasi dan persentase yang sama untuk responden yang lain tidak menerima insentif tambahan, dan selebihnya kadangkadang menerima insentif.

(8) Distribusi Profil Guru MIS dan Guru MIN

Nilai rata-rata antara distribusi data MIS dan MIN dalam penelitian ini sebagai berikut:

Tabel 8.Perbandingan Data MI dan MIN

\begin{tabular}{|c|c|c|c|c|}
\hline NO. & Dimensi & MIS & MIN & $\begin{array}{c}\text { Rata- } \\
\text { rata }\end{array}$ \\
\hline 1. & $\begin{array}{l}\text { Kompetensi } \\
\text { Kepribadian }\end{array}$ & 3,40 & 3,20 & 3,3 \\
\hline 2. & $\begin{array}{l}\text { Kompetensi } \\
\text { Pedagogik }\end{array}$ & 3,43 & 3,21 & 3,32 \\
\hline 3. & $\begin{array}{l}\text { Kompetensi } \\
\text { Profesional }\end{array}$ & 3,44 & 3,26 & 3,35 \\
\hline 4. & Kompetensi Sosial & 3,12 & 2,66 & 2,89 \\
\hline 5. & Learning Comunity & 3,09 & 2,79 & 2,94 \\
\hline 6. & $\begin{array}{l}\text { Latar belakang } \\
\text { Pendidikan }\end{array}$ & 3,34 & 3,28 & 3,31 \\
\hline 7. & $\begin{array}{l}\text { Finansial } \\
\text { Jumlah } \\
\text { Rata-rata } \\
\text { Rata-rata } \\
\text { keseluruhan }\end{array}$ & $\begin{array}{c}3,17 \\
22,99 \\
3,28 \\
6,4 / 2\end{array}$ & $\begin{array}{c}2,77 \\
21,17 \\
3,02\end{array}$ & $\begin{array}{c}2,97 \\
>1,82 \\
>0,16 \\
3,2\end{array}$ \\
\hline
\end{tabular}

Tabel di atas memberikan gambaran adanya perbedaan profil guru antara MIS dan MIN di Jakarta Selatan pada seluruh aspek meskipun tidak terlalu signifikan. Jumlah capaian untuk MIS adalah 22,99 sedangkan MIN 21,57 (selisih 1,42) dan rata-rata capaian adalah 3,28 untuk MIS dan MIN 3,08 (selisih 0,20). Hal ini berarti ada persamaan karakteristik profil guru yang profesional antara MIS dan MIN. Dengan demikian dapat disimpulkan bahwa profil guru MI unggulan di Jakarta Selatan dalam penelitian ini adalah para guru memiliki kompetensi kepribadian, pedagogik, profesional dan sosial yang baik.

Titik kelemahan yang perlu dibenahi khususnya di lingkungan MIN adalah dimensi kompetensi sosial (rata-rata 2,66), learning community (rata-rata 2,79) dan finansial (ratarata 2,77). Hal ini berarti kepala sekolah sebagai pimpinan dan para guru memiliki tanggung jawab untuk mengevaluasi kembali pentingnya tiga dimensi tersebut dan berupaya secara maksimal untuk mengembangkan dan menjadikan bagian dari upaya untuk meningkatkan kinerja guru. Kelemahan tersebut jika mampu diatasi lebih cepat maka akan mempengaruhi citra MIN unggulan menjadi lebih baik. Kasus pada MIN pada prinsipnya "kepala sekolah tidak diperbolehkan untuk melakukan pungutan, guru memperoleh tunjangan sertifikasi dan tunjangan kesra dari Pemerintah DKI."

\section{Penutup}

Beberapa temuan yang bisa disampaikan dalam penelitian ini adalah pertama, profil profesionalisme guru MI unggulan di Jakarta Selatan ditunjukkan oleh adanya kompetensi guru yang memadai dalam aspek kepribadian, pedagogik, profesionalisme, dan sosial. Kedua, pada dimensi learning community para guru belum sepenuhnya dapat mengembangkan diri

\footnotetext{
${ }^{7}$ Wawancara Pribadi, dengan Kepala Sekolah MIN Bintaro dan MIN Petukangan Jakarta Selatan.
} 
sebagai bagian masyarakat pembelajar sehingga bisa berpengaruh pada perkembangan MI unggulan itu sendiri. Ketiga, pada dimensi finansial dapat diketahui bahwa para guru khususnya MIN bersedia menerima seluruh kebijakan sistem imbalan yang ditetapkan oleh pemerintah dan oleh kepala sekolah mereka. Keempat, hal ideal yang sudah dicapai terkait latar belakang pendidikan adalah linieritas latar belakang pendidikan dengan profesi guru. Kelima, tidak adanya perbedaan yang menyolok dalam nilai rata-rata karakteristik profil profesionalisme guru MIS dan MIN ditinjau dari semua dimensi menunjukkan tingkat kepedulian yang sama baik MIS dan MIN terhadap prinsipprinsip profesionalitas jabatan guru.

Untuk itu, disarankan dalam mewujudkan profil profesionalisme guru MI yang unggul diperlukan peran aktif kepala sekolah untuk terus berupaya meningkatkan mutu kompetensi guru dengan melakukan berbagai kegiatan pengembangan guru baik dalam bentuk pelatihan, seminar, workshop maupun program kuliah lanjutan; Kepala sekolah perlu membuat kebijakan terkait peningkatan insentif para guru karena ada kesenjangan antara insentif guru MI dan SD akibat adanya kebijakan otonomi daerah.

Hal terpenting adalah upaya-upaya kepala Madrasah dalam mengembangkan keempat kompetensi para guru. Seperti pendapat yang dikemukakan oleh Tilaar, instrumen yang bisa digunakan untuk mengembangkan potensi para guru adalah misalnya: pelatihan, workshop, seminar dan pembinaan langsung seperti mengikutkan para guru dalam memecahkan masalah. ${ }^{8}$ Dalam kaitan ini pelibatan para guru sangat strategis dalam kerangka membangun loyalitas dan komitmen institusional sehingga akan melahirkan keberpihakan guru terhadap institusi. Fakta empirik di Madrasah sudah tampak yakni adanya kepala Madrasah yang secara rutin memprogramkan kegiatan pelatihan,

\footnotetext{
${ }^{8}$ Tilaar, Perubahan Sosial dan Pendidikan, Pengantar Pedagogik Transformative untuk Indonesia, (Jakarta: PT. Grasindo, 2002), h. 67.
}

seminar dan workshop setiap 3 bulan. Komitmen terhadap pengembangan guru menjadi kunci keberhasilan dalam mempertahankan prestasi yang sudah diraih dan menjadi peluang besar untuk meningkatkan daya saing Madrasah.

Sehingga para guru perlu meningkatkan kompetensi yang sudah dicapai dan meningkatkan kompetensi khususnya kompetensi sosial dalam kerangka untuk memberikan layanan yang terbaik bagi para siswa; disamping itu membangun learning community yang sebenarnya merupakan salah satu simbol eksistensi para guru sebagai masyarakat ilmiah. Fakta empirik yang menggambarkan belum sepenuhnya guru MI unggulan dapat mengembangkan diri melalui dimensi ini tentunya ini menjadi tantangan tersendiri bagi Madrasah.

Sebagai masyarakat pembelajar sudah selayaknya para guru tampil dan terlibat aktif dalam kegiatan pengembangan diri. Belajar tidak lagi dibatasi oleh waktu dan tidak lagi dihambat oleh keterbatasan itu sendiri, hal ini sesuai dengan pendapat dari Weigand.' Belajar perlu ditumbuhkan dan menjadi budaya para guru. Semakin intens fungsi dimensi ini maka semakin terbuka kemungkinan Madrasah menjadi maju dan berkembang pesat mengalahkan lembaga pendidikan lain setingkat. Madrasah tidak lagi dikenal sebagai lembaga pendidikan kelas dua akan tetapi menjadi kelas utama dan memainkan peran utama dalam pembentukan moralitas dan mentalitas siswa. Masih belum aktifnya fungsi dimensi learning community sudah seharusnya menjadi pertimbangan kepala Madrasah untuk segera mengambil tindakan penting terkait pembinaan dan pengembangan jaringan kelembagaan pendidikan bagi para guru.

Hal ideal yang ditunjukkan MI Unggulan adalah linieritas latar belakang pendidikan dengan profesi para guru. Linearitas pendidikan

\footnotetext{
${ }^{9}$ Weigand, J., Developing Teacher Competence, (New Jersey: Prenctice Hall, 1971), p. 90.
} 
menjadi sangat penting sebagai bentuk konsistensi bidang ilmu dengan profesi yang dipilih guru. Secara teoritis linearitas bidang ilmu juga berdampak pada aspek-aspek lain seperti motivasi kerja dan kinerja para guru di samping minat dan bakat. Dalam banyak kasus di Madrasah lazim ditemukan guru yang mengajar tidak sesuai bidang ilmunya atau dikenal dengan istilah miss-mach, tentunya hal ini akan berisiko terhadap tingkat kompetensi dan kinerja para guru serta Madrasah secara umum.

\section{Daftar Pustaka}

Depdiknas, UU RI No 20 Tentang Sistem Pendidikan Nasional, Jakarta: Departemen Pendididikan Nasional, Direktorat Jendral PendidikanLuar Sekolah dan Pemuda, 2003.

Undang-undang dan Peraturan Pemerintah RI tentangPendidikan, Jakarta: Direktorat Jenderal Pendidikan Islam DepartemenAgama RI., 2006.

, Standar Kompetensi Guru Kelas SD/MI Program D2 PGSD, Jakarta: P2TK Ditjen Dikti, 2002.

Direktorat Jenderal Pendidikan Nasional, Badan Standar Nasional Pendidikan", Jakarta: Departemen Pendidikan Nasional, 2006.
Lengkanawati, Nenden Sri, Tali Temali Pendidikan dan Pengembangan Profesionalisme Guru, "Pendidikan di Indoneisa: Masalah dan Solusi", Jakarta: Kemenko Kesra RI, 2008.

Makmun, Abin Syamsudin, Sistem Pendidikan dan Pengembangan Profesionalisme Guru, "Pendidikan di Indonesia: Masalah dan Solusi", Jakarta: Kemenko Kesra RI, 2008.

Mulyasa, E., Standar Kompetensi dan Sertifikasi Guru, Bandung: PT. Remaja Rosdakarya, 2009.

\section{Menjadi Guru Profesional.} Bandung. Remaja Rosdakarya, 2004.

Tilaar, Perubahan Sosial dan Pendidikan, Pengantar Pedagogik Transformatif untuk Indonesia, Jakarta: PT. Grasindo, 2002.

, Membenahi Pendidikan, 2002.

Zuchdi, Darmiyati, Humanisasi Pendidikan: Menemukan Kembali Pendidikan yang Manusiawi, Jakarta: Bumi Aksara, 2009.

Weigand, J., Developing Teacher Competence, New Jersey: Prenctice Hall,1971. 